\title{
Determination of selected steroid estrogens in treated sewage effluent in the Umsunduzi (Duzi) River water catchment area
}

Manickum $\mathrm{T}^{* *}$, John $\mathbf{W}^{1}$ and Terry $\mathrm{S}^{2}$

${ }^{1}$ Scientific Services Laboratories: Chemical Sciences, Engineering \& Scientific Services Division, Umgeni Water, P O Box 9 , Pietermaritzburg 3200 South Africa

${ }^{2}$ Water and Environmental Services, Umgeni Water

\begin{abstract}
Steroid hormones, naturally synthesized by human and animals, as well as synthetic/plant-derived ones usually in contraception, may be eventually released into the environment, especially in excreta. Levels of these hormones have been detected in significant concentration in sewage effluent around the world. These compounds have the ability, at very low concentrations, to alter normal functioning of the endocrine system, which is responsible for growth and development in vertebrate systems. Their eventual discharge into water bodies can affect reproduction and development in wildlife. Recycling of waste water for human domestic consumption necessitates the need to monitor the water quality of the effluent, as well as a check for these estrogens. Treated sewage effluent from the Darvill Waste Water Works (DWWW) is discharged into the Umsunduzi River; re-use options are being investigated. Samples were collected and assayed for estrone and 17-ß-estradiol (estradiol) by enzyme-linked immunosorbent assay (ELISA). The steroid hormone concentrations detected were similar to those reported for sewage effluent in Britain, Italy, Germany, Canada and The Netherlands. Preliminary removal efficiencies were noted to be comparable to those reported.
\end{abstract}

Keywords: Endocrine disrupting compound (EDC); Steroid estrogens; sewage effluent; ELISA; estradiol (E2); estrone (E1)

\section{Introduction}

Steroid hormones are biologically active compounds synthesized from cholesterol, with the common cyclopentano-perhydrophenanthrene ring in common [1]. Steroids include progestogens, glucocorticoids, mineralocorticoids, androgens, estrogens [2]. Natural steroids are secreted by the adrenal cortex, testis, and ovary, placenta in human and other animals. The estrogens estriol, estradiol (E2) and estrone (E1) (Figure 1), predominantly female hormones, are responsible for maintenance of reproductive organs and tissue, breast, skin and brain.

All humans and animals excrete hormones through their bodies; these hormones can end up in the environment through sewage discharge or animal waste disposal [2-5]. The steroid hormones,

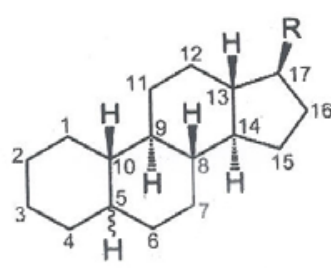

The basic skeleton of a steroid, with standard stereo orientations. $\mathbf{R}$ is a side-chain.
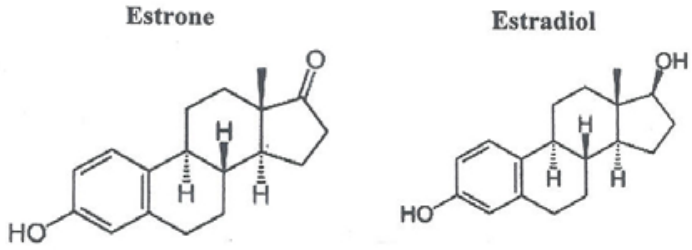

Figure 1: Structure of the steroid estrogens. chemically very stable, are excreted in the free form or as conjugates; the latter readily biotransform to the free conjugates $[4,6]$.

Steroids have been detected in sewage treatment plant effluents and in surface water [7-11]. Their eventual presence in the environment poses a significant potential problem of interference with normal function of the endocrine systems, and can thus affect reproduction and development in wildlife. The steroids of major concern in the aquatic environment, due to their endocrine disrupting potential, are mainly the estrogens.

Several studies, in the United Kingdom [7,12-15], continental Europe, Japan and North America [16-18], have shown the reproductive abnormalities exhibited by fish consistent with exposure to concentrations of estrogen, estrogen chemicals and estrogen mimics present in treated sewage water; their presence may be found to be impacting a wide range of fish species [19-21].

These estrogen hormones have also been reported to be present at varying levels (Table 1) [22] in effluents from sewage treatment works in Britain [7], Germany [9], Canada [9], The Netherlands [23], Italy [24] and the US [25].

Against a global rainfall average of $870 \mathrm{~mm}$ per year, South Africa receives a pitiful $450 \mathrm{~mm}$, making it the world's 30th driest country [26]. It has been reported that Durban could face water restrictions as early as next year [27]. There is thus a definite need to recycle water.

*Corresponding author: Dr. T. Manickum, Scientific Services Laboratories Chemical Sciences, Engineering \& Scientific Services Division, Umgen Water, P O Box 9, Pietermaritzburg 3200 KwaZulu-Natal, South Africa E-mail: Thavrin.manickum@umgeni.co.za

Received May 27, 2011; Accepted July 12, 2011; Published July 18, 2011

Citation: Manickum T, John W, Terry S (2011) Determination of selected steroid estrogens in treated sewage effluent in the Umsunduzi (Duzi) River water catchment area. Hydrol Current Res 2:117. doi:10.4172/2157-7587.1000117

Copyright: (c) 2011 Manickum T, et al. This is an open-access article distributed under the terms of the Creative Commons Attribution License, which permits unrestricted use, distribution, and reproduction in any medium, provided the original author and source are credited. 
The Darvill Waste Water Works, Pietermaritzburg, is the main sewage treatment plant for the Pietermaritzburg area, serving over 300 000 people. Treated sewage is then discharged directly into the adjacent Umsunduzi (Duzi) River. The process currently treats $75 \mathrm{ML} / \mathrm{d}$ through an activated sludge process, the modified Johannesburg biological nutrient removal process [28].

This river joins the Umgeni River, which is the main water supply to the Inanda dam. The latter supplies raw water to Durban Heights and Wiggins potable water treatment works, to supply potable water to the greater Durban area. Currently the dam supplies about $300 \mathrm{ML} / \mathrm{d}$.

As the Inanda impoundment $\left(\sim 240 \times 10^{6} \mathrm{~m}^{3}\right)$ has a retention time in the order of 2 years [29], estrogenic contaminants are not currently a concern [30]. However, direct recycling options are being considered.

A pilot project is currently investigating the use of membrane bioreactors (MBR), followed by advanced treatment, to treat waste water to a standard where it is drinkable [31]. The necessity of monitoring of the water quality is therefore a critical requirement to assess performance of the MBR.

Internationally, and also in South Africa, treated waste water effluent has to comply with certain legal requirements before discharge into natural water courses. However, there is currently no legislation in South Africa as regards maximum allowable levels of these estrogen hormones in water matrices.

To date, the only report on the estrogen levels in treated sewage effluent in South Africa was by Swart and Pool [32], in the Kuils River Water Catchment Area. Their results are listed in Table 1, under "South Africa". They reported $10.6 \mathrm{ng} / \mathrm{L}$, for estrone, and $4.7 \mathrm{ng} / \mathrm{L}$, for 17-ß-estradiol Table 2, using the Enzyme-linked immunosorbent assay (ELISA) $[33,34]$ technique.

Our main aim was therefore to determine, the presence, if any, of these steroid estrogens in the current (conventional) Darvill treated sewage effluent, and Umsunduzi River up- and down-stream and their corresponding concentrations. Some preliminary findings regarding the analytical techniques available, and the treatment plant efficiency of removal is also briefly reported on.

\section{Methodology}

\section{Sample collection}

As per the recommended procedure [32], glass bottles $(250 \mathrm{~mL})$

\begin{tabular}{|l|l|l|l|}
\hline Estrogen hormone & Country & $\begin{array}{l}\text { Minimum } \\
(\mathrm{ng} / \mathrm{L})\end{array}$ & $\begin{array}{l}\text { Maximum } \\
(\mathrm{ng} / \mathrm{L})\end{array}$ \\
\hline $17-ß-$ Estradiol & UK & 2.7 & 48 \\
\hline & Germany & $\mathrm{ND}^{\#}$ & 3 \\
\hline & Canada & $\mathrm{ND}^{\#}$ & 64 \\
\hline & Japan & 3.2 & 55 \\
\hline & South Africa & ND & 4.7 \\
\hline & & & \\
\hline Estrone & UK & 1.4 & 76 \\
\hline & Germany & $\mathrm{ND}^{\#}$ & 70 \\
\hline & Canada & $\mathrm{ND}^{\#}$ & 48 \\
\hline & & & \\
\hline & South Africa & $<0.2$ & 10.6 \\
\hline & Netherlands & $<0.4$ & 47 \\
\hline & Italy & 2.5 & 82.1 \\
\hline & & & \\
\hline
\end{tabular}

"ND = not detected

Table 1: Minimum and maximum levels of Estrogen hormones in selected treated sewage effluents collected from several countries.

\begin{tabular}{|c|c|c|c|c|c|}
\hline $\begin{array}{l}\text { Sample } \\
\text { Date }\end{array}$ & $\begin{array}{l}\text { Sample } \\
\text { Site } \\
\text { description }\end{array}$ & $\begin{array}{l}\text { Estrone } \\
\text { (ng/L) }\end{array}$ & $\begin{array}{l}\% \\
\text { Removal }\end{array}$ & $\begin{array}{l}\text { 17-ß- } \\
\text { Estradiol } \\
\text { (ng/L) }\end{array}$ & $\begin{array}{l}\% \\
\text { Removal }\end{array}$ \\
\hline \multirow[t]{4}{*}{$11 / 03 / 2010$} & Darvill influent & 13 & & 20 & \\
\hline & Darvill effluent & 3 & 77 & 5 & 75 \\
\hline & Duzi River u/s of Darvill & 2 & & 1 & \\
\hline & Duzi River $\mathrm{d} / \mathrm{s}$ of Darvill & 2 & & 2 & \\
\hline \multirow[t]{4}{*}{$01 / 11 / 2010$} & Darvill influent & 30 & & 33 & \\
\hline & Darvill effluent & 11 & 63 & 9 & 73 \\
\hline & Duzi River u/s of Darvill & 7 & & 12 & \\
\hline & Duzi d/s of Darvill & 2 & & 4 & \\
\hline \multirow[t]{4}{*}{$01 / 02 / 2011$} & Darvill influent & 42 & & 57 & \\
\hline & Darvill effluent & 16 & 62 & 18 & 68 \\
\hline & Duzi River u/s of Darvill & 3 & & 3 & \\
\hline & Duzi River d/s of Darvill & 5 & & 5 & \\
\hline
\end{tabular}

$\mathrm{u} / \mathrm{s}=$ control sample taken upstream of the Darvill WWW $\mathrm{d} / \mathrm{s}=$ control sample taken downstream of the Darvill WWW

Table 2: Estrogen levels in sewage influent and treated sewage effluent at DWWW.

were initially washed sequentially with: detergent, rinsed with running tap water, rinsed 4 times with distilled water and finally rinsed with 25 mL HPLC grade ethanol (99.5\% purity, from Merck). Inverted bottles and caps were allowed to dry on a drying rack. The head of the bottle was covered with foil before the cap was screwed on. In the absence of amber bottles, the clear glass was covered with foil. Collected water can be stored for 3 days at $4^{\circ} \mathrm{C}$. No additions to the sample were required. Samples were immediately couried "same day", packed with ice packs, to the testing laboratory, after collection.

"Control" or reference samples were collected from 2 points of the Duzi River: one sample just upstream $(\mathrm{u} / \mathrm{s})$ of the Darvill sewage treatment works, and another, downstream (d/s) of the Darvill effluent mixing zone.

As the city of Pietermaritzburg lies in the Duzi catchment upstream of the Darvill WWW, and as sewer problems are quite frequent, some detectable estrogens were considered likely.

\section{Analytical method for assay: ELISA}

The methods used for extracting and assaying environmental water samples for estrogenic compounds are described in detail in the paper by Swart and Pool [32]. These tests were extensively validated [32] using spiked, real water samples and the standards provided in the commercial kits. For estrone, the recovery averaged, over the range $15-2000 \mathrm{ng} / \mathrm{L}, 102.5 \pm 5.7 \%$. Intra-assay and inter-assay variation was $5.5 \pm 0.3 \%$ and $8.2 \pm 0.7 \%$ respectively. For estradiol, the recovery averaged, over the range $25-2000 \mathrm{ng} / \mathrm{L}, 95.8 \pm 9.0 \%$. Intra-assay and inter-assay variation was $8.9 \pm 1.0 \%$ and $3.9 \pm 0.1 \%$, respectively [32]

Samples were assayed for estradiol and estrone by ELISA, using the estradiol ELISA kit (cat. No. RE52041 IBL, Germany) and the estrone ELISA kit (Cat. No. DB 52051 IBL, Germany). The detection limits for both these estrogens are $1 \mathrm{ng} / \mathrm{L}$ [35].

\section{Accuracy study}

$\beta$-Estradiol and estrone (minimum 98\% purity) were purchased from Sigma-Aldrich (via local agents, Capital Lab Supplies). Methanol (gradient grade for liquid chromatography) was purchased from Merck.

\section{Statistical data analysis}

Student t-tests [36] were used to examine significant differences of 
the mean assay values between the two control sites and the influent/ effluent samples. A significance level of $\mathrm{P}<0.050$ was used.

\section{Results}

The observed tests results for the Darvill WWW to date are summarized in Table 2. The statistical data analysis for the comparison of the means of the Darvill samples with both control samples are summarized in Table 3.

\section{Estrone level in sewage effluent}

The mean influent level is $28 \mathrm{ng} / \mathrm{L}$ (Standard Deviation $(\mathrm{SD})=15$ ) for estrone. The corresponding mean effluent level is $10 \mathrm{ng} / \mathrm{L}(\mathrm{SD}=7)$.

For the Duzi River control samples, the mean level is $4 \mathrm{ng} / \mathrm{L}$ (SD = $3)$ and $3 \mathrm{ng} / \mathrm{L}(\mathrm{SD}=2)$ for the samples upstream and downstream of Darvill, respectively.

\section{Estradiol level in sewage effluent}

The mean influent level is $37 \mathrm{ng} / \mathrm{L}(\mathrm{SD}=19)$ for $17-\beta$ - estradiol. The corresponding mean effluent level is $11 \mathrm{ng} / \mathrm{L}(\mathrm{SD}=7)$.

For the Duzi River control samples, the mean level is $5 \mathrm{ng} / \mathrm{L}$ ( $\mathrm{SD}=$ $6)$ and $4 \mathrm{ng} / \mathrm{L}(\mathrm{SD}=2)$ for the samples upstream and downstream of Darvill, respectively.

\section{Removal efficiencies}

The calculated mean sewage works removal efficiencies are: $67 \%$ $(\mathrm{SD}=8)$ for estrone and $72 \%(\mathrm{SD}=4)$ for $17-\beta$-estradiol.

\section{Discussion}

\section{Occurrence and removal efficiency of E1 and E2}

The steroidal sex hormones, like estradiol and estrone, are naturally excreted into the environment from human and animal sources. Recent research has shown that such EDC's are present in municipal wastewater effluent. Untreated domestic sewage contains large concentrations of estrogen (40-300 ng/L), which is highly variable, depending on the source and dilution [43].

In primary treated wastewater, estradiol has been found to range from "not detected" (ND) to $150 \mathrm{ng} / \mathrm{L}$. For estrone, the range is 7.3$132 \mathrm{ng} / \mathrm{L}$. In secondary treated effluent, the reported ranges are ND43, and ND-108 ng/L, for estradiol and estrone [43]. The four main removal pathways for EDC's are: adsorption onto suspended solids,

\begin{tabular}{|l|l|l|l|l|}
\hline $\begin{array}{l}\text { Mean } \\
\text { Comparison }\end{array}$ & $\mathbf{Z}$ & $\begin{array}{l}\mathbf{t} \text { at } \mathbf{9 5 \%} \\
(\mathbf{P}=\mathbf{0 . 0 5 0})\end{array}$ & $\begin{array}{l}\text { Null } \\
\text { hypothesis } \\
\boldsymbol{H}_{0}: \mathbf{u}_{\mathbf{1}}=\mathbf{u}_{2}\end{array}$ & Result/decision \\
\hline Estrone & & & & \\
\hline u/s vs influent & 2.717 & 2.132 & $Z>t$ & Reject $H_{0}:$ means are different \\
\hline d/s vs influent & 2.861 & 2.132 & $Z>t$ & Reject $H_{0}:$ means are different \\
\hline u/s vs effluent & 1.289 & 2.132 & $Z<t$ & Accept $H_{0}:$ means not different \\
\hline d/s vs effluent & 1.665 & 2.132 & $Z<t$ & Accept $H_{0}:$ means not different \\
\hline & & & & \\
\hline $\mathbf{1 7 -} \beta$ - Estradiol & & & & \\
\hline u/s vs influent & 2.782 & 2.132 & $Z>t$ & Reject $H_{0}:$ means are different \\
\hline d/s vs influent & 2.992 & 2.132 & $Z>t$ & Reject $H_{0}:$ means are different \\
\hline u/s vs effluent & 1.127 & 2.132 & $Z<t$ & Accept $H_{0}:$ means not different \\
\hline d/s vs effluent & 1.666 & 2.132 & $Z<t$ & Accept $H_{0}:$ means not different \\
\hline
\end{tabular}

$\mathrm{u} / \mathrm{s}=$ control sample taken upstream of the Darvill WWW

$\mathrm{d} / \mathrm{s}=$ control sample taken downstream of the Darvill WWW

Table 3: Statistical data analysis for comparison of mean results for samples and controls. aerobic and anaerobic biodegradation, chemical (abiotic) degradation via processes such as hydrolysis, and volatilization. In general, research has supported the strongest role for adsorption and biodegradation for the removal of such compounds.

The octanol-water partitioning coefficients $\left(\mathrm{K}_{\mathrm{ow}}\right)$ of hormones suggest that they should sorb to mixed liquor suspended solids (MLSS) before significant degradation occurs. Sorption to solids has been found to be an important removal mechanism. The highest estrogenic activity was found in the digested biosolids. Hormones were adsorbed onto biosolids as the primary removal mechanism with the estradiol concentration of the biosolids 1,000 times greater than the secondary effluent concentration.

Biodegradation of estradiol and estrone has also been demonstrated. Effluent concentrations of estrone were reported at higher levels than influent concentrations for four of six sampling events, likely due to oxidation of estradiol to estrone during the treatment process. Similar activated sludge batch experiments found that estradiol was removed with concomitant increase in estrone. Estrone was biodegraded in both studies with longer incubation.

Unfortunately a fair amount of research reporting removal of estrogenic activity in wastewater treatment facilities fails to report operational parameters at the facilities studied. The latter omission has made it difficult to correlate the relationship between operational parameters and percent removal. Many studies have suggested that increased solids retention times (SRT's) result in an improved removal of hormones in wastewater treatment facilities. Hydraulic retention time (HRT) has also been found to have positive correlation with hormone removal. Higher SRT's resulted in greater percentage removal of the hydrophobic compounds being studied and suggested a minimum SRT is required for removal of such EDC's.

The ability of advanced treatment technologies, like reverse osmosis and nanofiltration membrane, membrane bioreactors, ultraviolet disinfection, and activated carbon adsorption, to remove such EDC compounds, is an area of active research.

\section{Removal of EDC's during advanced treatment technology}

MBR technology is often considered a promising development in wastewater treatment, integrating biological degradation of waste products with membrane filtration. These treatment systems are effective in removing organic and inorganic compounds as well as biological contaminants from wastewater. Steroid removal rates of $90 \%$ were achieved in membrane bioreactors with nitrification and denitrification [45]. Biological degradation has been cited as the most important factor in the removal of estrogens and other endocrine disruptors in membrane bioreactors [45]. It was found that two membrane bioreactors, Zenon and Mitsubisi, provided almost complete removal of the steroid estrogens [45].

\section{Estrogen analysis}

Estrogenic hormones in water can be determined by various techniques, such as gas chromatography (GC), gas chromatographymass spectrometry (GC-MS), GC-MS/MS, high performance liquid chromatography (HPLC), HPLC-MS and HPLC-MS/MS [37,38] Although these methods are reliable, some of their disadvantages are high initial capital cost of the equipment, complex derivatisation, extensive sample clean-up, purification and the requirement for staff with high technical expertise. One advantage of the HPLC-MSMS method is the ability to screen for various other compounds of different classes, like the steroid estrogens, and other endocrine disrupting 
compounds (EDC's) in the same run, not possible by the ELISA [33, 34], which is compound class-specific.

Due to the fact that Umgeni Water Laboratory Services do not currently offer these tests, a study was conducted to establish testing centers in the country for the purposes of routine monitoring of these steroid estrogens present in the influent and effluent at DWWW. Three centers were initially found to conduct these tests: Du Buisson (Gas chromatography-mass spectrometry (GC-MS) method) [39] (2009), FDA Laboratories [40] (Swemmer, 2010) (HLPLC-tandem mass spectrometry (MS) method) and University of Western Cape (UWC) [32] (Pool, 2010) ((ELISA) method). It was more recently established that the University of the Free State (UFS)/LiquidTech [41] (Kemp, 2011) (HLPLC-tandem mass spectrometry method) also offers estrogen tests.

The sensitivity of the HPLC-MSMS method for these hormones varies from $1000 \mathrm{ng} / \mathrm{L}[39,41]$ to as low as $10 \mathrm{ng} / \mathrm{L}$ [40] (Swemmer, 2010), at best.

The ELISA assay was adequately validated by Swart and Pool [32], with good limits of detection (1 ng/L for both estrone and estradiol), and the work was also published in an international journal. For these reasons, it was initially decided to send samples to the University of Western Cape.

Currently, there is no World Health Organization (WHO) levels or limits for 17-ß-estradiol and estrone, or any of the other estrogen hormones, in their Guidelines for Drinking Water Quality (3 ${ }^{\text {rd }}$ Edition WHO, 2008) [42]. However, 17-ß-estradiol, estrone and 17- $\alpha$-ethinylestradiol are all included in the Environmental Protection Agency (EPA) Candidate List 3 (CCL 3) [43]. This is a list of contaminants, 104 in total, that are currently not subject to any proposed or promulgated national primary drinking water regulations, that are known or anticipated to occur in public water systems, and which may require regulation under the Safe Drinking Water Act (SDWA) in the United States [43] (EPA). These three hormones are also part of the list verified as potential EDC's in the recent study by Benotti et al. [44]. They also form part of the EDC package test performed by LiquidTech, University of the Free State.

Reported raw sewage influent levels in the literature range from: 0.5 to $670 \mathrm{ng} / \mathrm{L}$ for estrone, $<0.3$ to $224 \mathrm{ng} / \mathrm{L}$ for $17-\beta$-estradiol, $2-660 \mathrm{ng} / \mathrm{L}$ for estriol and $0.4-13 \mathrm{ng} / \mathrm{L}$ for $17-\alpha$-ethinylestradiol $[11,45]$.

The first study on estrogen hormones levels, conducted in South Africa, was by Poole and Swart [32], on the sewage effluents from the treatment plants in the Kuils River Water Catchment Area (Table 1) [32].

Our preliminary results (Table 2) are also similar to the lower range detected in sewage effluent from Britain, Italy, Germany, Canada and The Netherlands (Table 1) [22]. However, concentrations as low as 1 $\mathrm{ng} / \mathrm{L}$ of $17-\beta$-estradiol led to vitellogenin $[46,47]$ in male trout [48]; it was observed that ova formed in the testis of Japanese medaka [49] at a low concentration of $4 \mathrm{ng} / \mathrm{L}$ of $17-\beta$-estradiol [50]. This indicates that even these observed low concentrations may remain a concern.

Comparison of the mean control samples with the Darvill influent samples showed a significant difference for both estrone and estradiol (Table 3). However, the control samples were not significantly different when compared to the Darvill treated effluent samples. The relatively lower estrogen levels in the effluent are to be expected due to the removal efficiency of the activated sludge process at the sewage treatment works.
With the activated sludge treatment process, a study of the literature indicates that estrone will not be completely removed. The reported removal performance for estrone shows variation - $61 \%$ has been reported in the literature, whilst $>85 \%$ removal efficiency has been reported for 17-ß-estradiol $[11,45]$. Preliminary results obtained for the DWWW shows a similar removal efficiency of $67 \%$, for estrone, and of $72 \%$ for $17-\beta$-estradiol.

Over the sampling period, the Darvill area sampling data (Table 2) indicated significant variation in concentrations received (up to three times) in the raw sewage. Removal efficiencies however remained constant. The data confirm the presence of estrogens in the river upstream as well as downstream of the sewage treatment works, indicating sources in the city of Pietermaritzburg. Even when effluent concentrations were relatively high $(01 / 02 / 2011)$, downstream concentrations remained almost unaffected, at least partly due to significant dilution during the summer rainfall period.

The ELISA test method for estrogen assay appears to be more sensitive than the HPLC tandem MS method: $1 \mathrm{ng} / \mathrm{L}$ can be detected for both estrone and 17-ß-estradiol by ELISA [22,32], while the corresponding reported limits of quantitation are generally, at best, 10 ng/L for the HPLC-MSMS technique. This appears to be inadequate for environmental quantification requirements.

To check the accuracy of the ELISA assay, real samples from the Darvill WWW were taken and spiked at $20 \mathrm{ng} / \mathrm{L}$ with a commercial composite of E1 and E2, prepared in methanol. They were submitted to UWC for assay of E1 and E2 by ELISA. The results are summarized in Table 4.

Imprecision: The Darvill Final and Pilot Plant permeate are relatively cleaner matrices (much less suspended solids compared to Darvill raw and we should expect better precision. However, 25 and $33 \%$ relative standard deviation (RSD) was calculated for estrone and 17-ß-estradiol. For Darvill raw, which has relatively more suspended solids, the corresponding imprecision was 10 and $0 \%$ RSD, for estrone and 17- $\beta$-estradiol, respectively. However, only 2 replicates were submitted $(\mathrm{n}=2)$. The average imprecision (unspiked and spiked samples) observed is: $16 \%$ for estrone and $22 \%$ for 17 - $\beta$-estradiol.

Accuracy (by recovery): Abnormally high recovery was obtained for estrone for Darvill raw spiked (180\%) and for Duzi u/s Darvill spiked for estradiol (155\%). Very low recovery was obtained for estrone for Duzi u/s Darvill and for estrone for Duzi d/s Darvill. The average recovery (accuracy) is: $86 \%$ for estrone and $105 \%$ for 17 - $\beta$-estradiol.

One possible reason for these discrepancies is that spiking must be done with steroid in dimethyl sulfoxide solvent. Alcohols, like methanol, which was used in our "spiking" study, do not result in consistent recoveries - due to steroid being at local high and precipitate at point of entry into sample [35].

The overestimation caused by matrices in environmental samples is considered to be an inherent problem with some ELISA methods. More recent related research on ELISA test methods and kits for estrogen assay have been reported [50-53]. Hirobe et al. [54] developed ten kinds of ELISA systems for quantitative analysis of endocrine disruptors, surfactants and estrogens for the analysis of environmental and biological samples; these samples included influent and effluent samples from a sewage treatment plant as well. Good correlations were observed between the ELISA's and instrumental analytical methods, like high performance liquid chromatography, and tandem mass spectrometry in all cases. They [54] recommended that a proper 
Citation: Manickum T, John W, Terry S (2011) Determination of selected steroid estrogens in treated sewage effluent in the Umsunduzi (Duzi) River water catchment area. Hydrol Current Res 2:117. doi:10.4172/2157-7587.1000117

Page 5 of 7

\begin{tabular}{|c|c|c|c|c|c|}
\hline \multirow{2}{*}{$\begin{array}{l}\text { Sample } \\
\text { number }\end{array}$} & \multirow[t]{2}{*}{ Actual Description/site } & \multirow{2}{*}{$\begin{array}{l}\text { Estrone } \\
\text { (ng/L) }\end{array}$} & \multirow{2}{*}{$\begin{array}{l}\text { \% Recovery/ } \\
\text { Accuracy }\end{array}$} & \multirow{2}{*}{$\begin{array}{l}\text { 17- } \beta \text {-Estradiol } \\
\text { (ng/L) }\end{array}$} & \multirow{2}{*}{\begin{tabular}{|l}
$\%$ Recovery/ \\
Accuracy
\end{tabular}} \\
\hline & & & & & \\
\hline 1 & Darvill influent/raw & 39 & & 57 & \\
\hline \multirow[t]{4}{*}{2} & Darvill inflent/raw duplicate & 45 & & 57 & \\
\hline & mean & 42 & & 57 & \\
\hline & $\mathrm{SD}^{\#}$ & 4 & & 0 & \\
\hline & RSD\%* & 10 & & 0 & \\
\hline 3 & Darvill influent/raw spiked & 78 & 180 & 70 & 65 \\
\hline 4 & Darvill effluent/ final & 13 & & 22 & \\
\hline \multirow[t]{4}{*}{5} & Darvill effluent/final duplicate & 18 & & 14 & \\
\hline & mean & 16 & & 18 & \\
\hline & SD & 4 & & 6 & \\
\hline & RSD \% & 25 & & 33 & \\
\hline 6 & Darvill effluent/final spiked & 34 & 90 & 41 & 115 \\
\hline 7 & Duzi upstream Darvill & 3 & & 3 & \\
\hline 8 & Duzi upstream Darvill spiked & 13 & 50 & 34 & 155 \\
\hline 9 & Duzi downstream Darvill & 5 & & 5 & \\
\hline 10 & Duzi downstream Darvill spiked & 10 & 25 & 22 & 85 \\
\hline 11 & Pilot plant permeate/final & 34 & & 7 & \\
\hline \multirow[t]{11}{*}{12} & Pilot plant permeate/final duplicate & 29 & & 11 & \\
\hline & mean & 32 & & 9 & \\
\hline & SD & 4 & & 3 & \\
\hline & RSD \% & 13 & & 33 & \\
\hline & Overall means & precision & accuracy & precision & accuracy \\
\hline & & 10 & 180 & 0 & 65 \\
\hline & & 25 & 90 & 33 & 115 \\
\hline & & 13 & 50 & 33 & 155 \\
\hline & & & 25 & & 85 \\
\hline & mean & 16 & 86 & 22 & 105 \\
\hline & SD & 8 & 68 & 19 & 39 \\
\hline
\end{tabular}

${ }^{\#} R S D$ = relative standard deviation

${ }^{*} S D=$ standard deviation

Table 4: Accuracy check of the ELISA test.

cleanup method can eliminate such problems of over- or underestimation because of cross reactivity or matrix effects: for example, use of dichloromethane as elution solvent of choice for solid phase extraction.

The obstacle faced by Swart and Pool [32] was the fact that the commercial ELISA kits were optimized for quantitation of estrogen in blood serum. However, their validation work of these kits for steroid hormone assay in sewage effluent showed that the kits are highly repetitive, with minimal inter- and intra-assay ELISA kit interference. This was further supported by good parallelism between dilution curves of the kit standards and sewage effluent samples [32].

There are plans to have the ELISA method set up "in-house" at Umgeni Water laboratory. In the light of a recent publication [55], the option of using GC-MS for the subsequent assay of these compounds at Laboratory Services, Umgeni Water is being seriously considered. Until this, or another suitable test method is developed and validated "in-house", samples will be outsourced to UWC in the interim.

\section{Conclusion}

To date, this is the second report on detection of steroid estrogens in water catchment areas in South Africa, and also the first report for the Umsunduzi (Duzi) River water catchment area, Kwa-Zulu-Natal region.

The steroid hormone concentrations detected were similar to those reported for treated sewage effluent in Britain, Italy, Germany, Canada and The Netherlands. Percentage removals were consistent but significant variation was noted in samples over the one year period.

Further sampling for estrogen monitoring at DWWW, is required on a long-term basis ( \pm 1-2 years). The accuracy, and imprecision, of the test methods and results also need to be better evaluated. The latter will assist in making more definitive, meaningful conclusions.

\section{Acknowledgement}

The authors acknowledges Professor E Pool, UWC, for the estrogen ELISA assays, Debbie Trollip (Process Services, Darvill WWW) and Alistair Hunter (Water and Environmental Services), Head Office, for the collection of samples.

\section{References}

1. Raven PH, Johnson GB (1999) Biology. $5^{\text {th }}$ Edition; WCB/McGraw- Hill: Boston.

2. Lintelmann L, Katayama A, Kurihara N, Shore L, Wenzel A (2003) Endocrine disruptors in the environment (IUPAC Technical Report). Pure Appl Chem 75: 
Citation: Manickum T, John W, Terry S (2011) Determination of selected steroid estrogens in treated sewage effluent in the Umsunduzi (Duzi) River water catchment area. Hydrol Current Res 2:117. doi:10.4172/2157-7587.1000117

Page 6 of 7

$631-681$

3. Shore LS, Shemesh M (2003) Naturally produced steroid hormones and their release into the environment. Pure Appl Chem 75: 1859-1871.

4. Wenzel A, Kuechler TH, Muller J (1998) Konzentrationen oestrogen wirksame Substanzen in Umweltmedien. Project sponsored by the German Environmental Agency: Project No: 21602 011/11

5. Wise A, 'O Brien K, Woodruff T (2011) Are oral contraceptives a significan contributor to the estrogenicity of drinking water? Environ Sci Technol 45: 51 60.

6. Panther GH, Thompson RS, Beresford N, Sumpter JP (1999) Transformation of a non-oestrogenic steroid metabolite to an oestrogenically active substance by minimal bacterial activity. Chemosphere 38: 3579-3596.

7. Desbrow C, Routledge EJ, Brighty GC, Sumpter JP, Wladock M (1998) Identification of estrogenic chemicals in STW effluent: 1. Chemical fractionation and in vitro biological screening. Envir Sci Technol 32: 1549-1558.

8. Kuch HM, Ballschmitter K (2001) Determination of endocrine-disrupting phenolic compounds and estrogens in surface and drinking water by HRGC(NCl)-MS in the picogram per litre range. Envir Sci Technol 35: 3201-3206

9. Ternes TA, Stumpf M, Mueller J, Haberer K, Wilken RD, et al. (1999) Behaviour and occurrence of estrogens in municipal sewage treatment plants. Investigations in Germany, Canada, and Brazil. Sci Total Envir 225: 81-90.

10. Quanrad D, Propper CR (2010) Wastewater effluent: biological impacts of exposure and treatment processes to reduce risk. The Nature Conservancy Centre for Science and Public Policy.

11. Koh YK, Chiu TY, Boobis A, Cartmell E, Scrimshaw MD, et al. (2008) Treatment and removal strategies for estrogens from wastewater. Environ Technol 29: 245-267.

12. Jobling S, Nolan M, Tyler CR, Brighty G, Sumpter JP (1998) Widespread sexual disruption in wild fish. Environ Sci Technol 32: 2498-2506.

13. Harries JE, Sheahan DA, Jobling S, Matthiessen P, Neall P, et al. (1996) A survey of estrogenic activity in United Kingdom inland waters. Envir Toxicol Chem 15: 1993-2002.

14. Jobling S, Tyler CR (2003) Endocrine disruption in wild freshwater fish. Pure Appl Chem 75: 2219-2234.

15. Purdom C, Hardiman P, Bye V, Eno N, Tyler C, et al. (1994) Estrogenic effects of effluents from sewage treatment works. Chem Ecol 8: 275-285

16. Korner W, Spengler P, Bolz U, Schuller W, Hanf V, et al. (2001) Substances with estrogenic activity in effluents of sewage treatment plants in southwestern Germany. 2. Biological analysis. Environ Toxicol Chem 20: 2142-2151.

17. Onda K, Yang SY, Miya A, Tanaka T (2002) Evaluation of estrogen-like activity on sewage treatment processes using recombinant yeast. Water Sci Technol 46: 367-373.

18. Sole M, MJL de Alda, Castillo M, Porte C, Ladegaard-Pedersen K, et al. (2002) Estrogenicity determination in sewage treatment plants and surface waters from the Catalonian area (NE Spain). Environ Sci Technol 34: 5076-5083.

19. Christiansen L, Winther-Nielsen M, Helweg C (2002) Feminization of fish: The effect of estrogenic compounds and their fate in sewage treatment plants and nature. Danish Envir Prot Agency.

20. Folmar LC, Denslow ND, Kroll K, Orlando EF, Enblom J, et al. (2001) Altered serum sex steroids and vitellogenin induction in walleye (Stizostedion vitreum) collected near a metropolitan sewage treatment plant. Arch Environ Contam Toxicol 40: 392-398.

21. Hashimoto S, Bessho H, Hara A, Nakamura M, Iguchi T, et al. (2000) Elevated serum vitellogenin levels and gonadal abnormalities in wild male flounder (Pleuronectes yokohamae) from Tokyo Bay, Japan. Mar Environ Res 49: 37-53.

22. Reproduced with kind permission of Professor Pool E, UWC.

23. Belfroid AC, Van der Horst A, Vetahhk AD, Schafer AJ, Ris GBJ, et al. (1999) Analysis and occurrence of estrogenic hormones and their glucuronides in surface water and waste water in the Netherlands. Sci Total Environ 225: 101 108

24. Baronti C, Curini R, GD’Asecnzo, Di Corcia A, Gentilli A, et al. (2000) Monitoring natural and synthetic estrogens at activated sludge sewage treatment plants and in a receiving river water. Environ Sci Technol 34: 5059-5066.

25. Kolpin DW, Furlong ET, Meyer MT, Thurman EM, Zaugg SD (2002) Pharmaceuticals, hormones, and other organic waste-water contaminants in U.S. streams, 1999-2000. A national reconnaissance. Environ Sci Technol 36 1202-1211.

26. Water Rhapsody.

\section{SA WEATHER AND DISASTER INFORMATION SERVICES 2010}

28. Wilson, Thomas E, McGettigan, John (2006) A Critical new look at nutrient removal processes. Earth Tech Inc pp 3491-3501.

29. Sithole S (2011) Hydrologist: Planning Services, Umgeni Wate

30. Terry S (2011) Scientist: Water and Environmental Services, Umgeni Water

31. Metcalf G (2010) Darvill water reclamation for potable use. Flowmeter. Umgen Water

32. Swart N, Pool E (2007) Rapid detection of selected steroid hormones from sewage effluents using an ELISA in the Kuils River water catchment area, South Africa. J Immunoassay Immunochem 28: 395-408.

33. Crowther JR (1995) Methods in Molecular Biology. Basic principles of ELISA 42: $35-61$.

34. Hongbao M, Kuan-Jiunn S, Sheau-Long L (2006) Study of ELISA. Technique Nature and Science 4: 36-37.

35. Pool E (2011) Personal Communication. Professor, Department of Medical Biosciences, University of Western Cape.

36. Willemse I (1990) Statistical Methods and Financial Calculations; Juta Academic, pp 127-155

37. Snyder SA, Keith TL, Verbrugge DA, Snyder EM, Gross TS, et al. (1999) Analytical methods for detection of selected estrogenic compounds in aqueous mixtures. Environ Sci Technol 33: 2814-2820.

38. Snyder SA, Villeneuve DL, Snyder EM, Giespy JP (2001) Identification and quantification of estrogen receptor agonists in wastewater effluents. Environ Sci Technol 35: 3620-3625.

39. Schillak V (2009) Esoteric Science National Coordinator: Drs Du Buisson, Kramer, Swart, \& Bouwer Inc.

40. Swemmer A (2010) Technical Director, Food and Drug Assurance Laboratories Pretoria.

41. Kemp G (2011) Manager, Facility for Genomics and Proteomics (FGAP), ABSciex Demo Lab Department for Microbial Biochemical and Food Biotechnology, University of the Free State Bloemfontein.

42. World Health Organization (WHO) (2008). Guidelines for Drinking-wate Quality: 1: Recommendations, $3^{\text {rd }}$ Edition.

43. United States Environmental Protection Agency (EPA) Drinking water contaminants.

44. Benotti MJ, Rebecca AT, Brett JV, Holady JC, Stanford BD, et al. (2009) Pharmaceuticals and endocrine disrupting compounds in U.S. drinking water Environ Sci Technol 43: 597-603.

45. Drewes JE, Hemming JDC, Schauer JJ, Sonzogni WC (2006) Report Number: 01-HHE-20T: Removal of endocrine disrupting compounds in water reclamation processes. Water Environment Research Foundation.

46. Vitellogenin. Wikipedia, the free encyclopedia.

47. Vitellogenin. Miriam-Webster Dictionary

48. Hansen PD, Dizer H, Hock B, Marx A, Sherry J, et al. (1998) Vitellogenin- a biomarker for endocrine disruptors. Trends Anal Chem 17: 448-451. 
Citation: Manickum T, John W, Terry S (2011) Determination of selected steroid estrogens in treated sewage effluent in the Umsunduzi (Duzi) River water catchment area. Hydrol Current Res 2:117. doi:10.4172/2157-7587.1000117

Page 7 of 7

49. Japanese medaka. Pam Fuller and Leo Nico (2011) Oryzias latipes. USGS Nonindigenous Aquatic Species Database, Gainesville, FL.

50. Metcalfe CD, Metcalfe TL, Kiparissis Y, Koenig BG, Khan C, et al. (2001) Envir Toxicol Chem 20: 297-308.

51. Verification of Enzyme-linked Immunossorbent Assay (ELISA) test Kits for the Quantitative Determination of Endocrine Disrupting Compounds (EDC's) in Aqueous Phase Samples (2008)

52. Buehler S, Willenberg Z, Dindal A, Kleiner BE, Henderson M, et al. (2009) Abraxis 17- $\beta$-Estradiol (E2) magnetic particle enzyme-linked immunosorbent assay (ELISA) test kits. Environmental Technology Verification Report.
53. Buehler S, Willenberg Z, Dindal A, Kleiner BE, Henderson M, et al. (2009) Abraxis ecologenia ethynylestradiol (EE2) microplate enzyme-linked immunosorbent assay (ELISA) test kits. Environmental Technology Verification Report.

54. Hirobe M, Rubio F, Fujita M, Shiraishi H (2004) Development of ELISA's for quantification of surfactants, endocrine disruptors and estrogens, and their application for environmental and biological sample analysis.

55. Hu R, Zhang L, Yang Z (2010) Picogram determination of estrogens in water using large volume injection gas chromatography-mass spectrometry. Anal Bioanal Chem 390: 349-359. 